\title{
Medical follow-up for workers exposed to bladder carcinogens: the French evidence-based and pragmatic statement
}

\author{
Bénédicte Clin 1,2*, "RecoCancerProf" Working Group and Jean-Claude Pairon 3,4
}

\begin{abstract}
Background: The aim of this work was to establish recommendations for the medical follow-up of workers currently or previously exposed to carcinogenic substances for the bladder.

Methods: A critical synthesis of the literature was conducted. Sectors of activity where workers are or were exposed to carcinogenic substances for the bladder were listed and classified according to the level of bladder cancer risk. Performances of techniques available for the targeted screening of bladder cancer were analysed, including a simulation of results among high-risk populations in France.

Results: The risk level for the professional group and the latency period between the start of exposure and the natural history of the disease were selected to define a targeted screening protocol. The NMP22BC test, exclusive haematuria testing, and combinations of urine cytology with, respectively, the NMP22BC test and haematuria test, generated an extremely high proportion of false positive results.

Conclusion: Urine cytology is the test that offers the best specificity. Although poor for all bladder cancer stages and grades combined, its sensitivity is better for high grades, which require early diagnosis since late-stage cancers are of very poor prognosis. These results suggest that urine cytology is currently the only technique suitable for proposal within the context of a first line targeted screening strategy for occupational bladder cancer. An algorithm summarising the recommended medical follow-up for workers currently or previously exposed to carcinogenic substances for the bladder is proposed, based on the level of risk of bladder cancer.
\end{abstract}

Keywords: Bladder cancer, Occupational exposure, Medico-professional follow-up, Recommendations

\section{Background}

With an estimated incidence of 386,000 cases of bladder cancer worldwide in 2008 and over 150,000 deaths, bladder cancer is the 9th cause of cancer in the world and the 8 th cause of death by cancer in men [1,2]. In France, bladder cancer is the 7th cause of cancer and the 8th cause of death by cancer in men, with an estimated incidence of 10,729 cases in 2009 , causing over 4,500 deaths [3]. The annual incidence rates for this cancer in men

\footnotetext{
* Correspondence: clin-b@chu-caen.fr

${ }^{1}$ Cancers and prevention, U1086 INSERM, Faculty of Medicine, Caen University Hospital, Caen, France

${ }^{2}$ Service de Santé au Travail et Pathologie Professionnelle (Occupational Health Department), C.H.U. (University Hospital) Côte de Nacre, 14033 CAEN Cedex, France

Full list of author information is available at the end of the article
}

and women in France were respectively 14.7/100000 and 2.5/100000 in 2012 [4].

Besides tobacco smoking, occupational exposure to carcinogens is another major risk factor for bladder cancer. Indeed, according to study results, the proportion of bladder cancers attributable to occupational exposure ranges from 5 to 25\% in men [5-8]. In 2001, the InVS (Institut de Veille Sanitaire) estimated that, in France, 8 to $14 \%$ of incident cases of bladder cancer and 10 to $14 \%$ of deaths linked to this type of cancer in men were attributable to occupational exposure, representing 625 to 1,110 incident cases and 347 to 492 deaths by bladder cancer in 1999 [8]. The most frequent occupational sectors where excess rates of bladder cancer are observed are those exposing (or having exposed) workers to aromatic amines, nitrosamines and polycyclic aromatic hydrocarbons (PAHs). In 
France, even if measures have been taken to prohibit the use of carcinogens such as certain aromatic amines, and although preference has been given to the use of certain substitute products (e.g. bitumen instead of coal tar), certain industrial sectors remain implicated in exposure to bladder carcinogens (in particular, those using o-toluidine, o-tolidine, o-anisidine and MBOCA, and those using products containing secondary amines likely to react with nitrosating compounds). Priority must therefore be placed on implementing primary preventive measures on these sites.

The latency after the start of exposure to a carcinogenic substance for the bladder is estimated between 14 and 26 years [9] and appears rarely to fall under 20 years [10]. In the majority of cases, urothelial tumours appear after the age of 60 years $[2,11]$. According to data from the international literature on the subject, bladder cancer screening in the general population is not recommended, due, in particular, to the disease's low prevalence [12]. Furthermore, no study has been conducted relying on a sufficiently large sample of individuals to assess the relevance of bladder cancer screening in high-risk populations. Nevertheless, according to an international panel of experts (International Consensus Panel on Cytology and Bladder Tumour Markers), reunited in 2005, individual screening in high-risk subjects such as smokers, occupationally-exposed subjects and subjects with a genetic predisposition could be considered using, in particular, urinary makers associated or not with conventional cytology [13].

Data from the literature on our knowledge of certain occupational risk factors and dose-response relationships are as yet limited, as it is on bladder cancer screening tools and protocols. We therefore deemed absolutely necessary the compilation of a synthesis of available data, in order to determine associated strategy(ies) suitable for recommendation.

We deemed necessary to assess the efficiency of new techniques used in urology for the early diagnosis of bladder cancer recurrence, in order to rationalise medicoprofessional monitoring modalities for subjects presenting a high risk of bladder cancer.

The management of occupational carcinogenic risk for the bladder relies on both a technical preventive approach (i.e. the implementation of preventive measures, e.g. suppression or limitation of the exposure to occupational carcinogens) and on specific medical follow-up. We deliberately focus here on this second aspect. Indeed, the aim of this work was to define modalities for the medical follow-up of workers currently or previously exposed to carcinogenic substances for the bladder, which are adapted to exposure situations and coherent with current knowledge on dose-response relationships, evolutive characteristics and therapeutic options for the treatment of bladder cancer. We consequently defined target populations depending on risk levels and proof levels based on analysis of the scientific literature, together with the current more appropriate screening tool and frequency of screening.

\section{Methods}

\section{Population concerned}

These medical recommendations target all healthcare professionals involved in primary and secondary prevention of bladder cancer, to employers and to workers currently or previously exposed to carcinogenic substances for the bladder, whether they are still active or not and independently of their professional status.

Healthcare professionals include the occupational physician and the other members of the pluridisciplinary occupational health team (occupational health nurse and professionals involved in primary prevention of occupational risks) during the worker's period of professional activity, then the general practitioner and/or urologist, or other healthcare professionals (e.g. in occupational disease consultation centres - within the context of post-occupational follow-up, oncology networks and anatomopathologists).

\section{Method}

The subject of our study is vast and raises a number of questions and sub-questions. Available scientific data are highly dispersed and difficult to summarise; however, in principle, the subject does not require the initiation of a public debate. Furthermore, the most appropriate method appeared to be the RPC "Clinical Practice Guidelines" method, recommended by the HAS (French National Authority for Health). Analysis and critical synthesis of the scientific literature were conducted according to principles of critical reading, in order to attribute a level of scientific proof to each article, according to the classification recommended by the HAS (Table 1).

No randomised studies of occupational risk factors are usually conducted in the working environment. In contrast, there have been several "well-conducted" studies, taking into account confounding factors and potential dose-response relationships, together with a number of studies with concordant results. We consequently considered that meta-analysis or systematic reviews on wellconducted cohort studies offered level 1 scientific proof. We considered that cohort studies which were "wellconducted non-randomised studies" offered level 2 scientific proof, whereas, case-control studies were considered as offering level 3 scientific proof.

Due to a lack of available studies, recommendations are based on expert consensus within the framework of a work group after consultation with the reading group. 


\begin{tabular}{|c|c|}
\hline $\begin{array}{l}\text { Level of scientific proof provided by the } \\
\text { literature (for clinical studies) }\end{array}$ & $\begin{array}{c}\text { Recommendation } \\
\text { grading }\end{array}$ \\
\hline \multicolumn{2}{|l|}{ Level 1} \\
\hline - High-power randomised comparative studies & A \\
\hline $\begin{array}{l}\text { - Meta-analysis of randomised comparative } \\
\text { studies }\end{array}$ & $\begin{array}{l}\text { Scientific proof } \\
\text { established }\end{array}$ \\
\hline \multicolumn{2}{|l|}{$\begin{array}{l}\text { - Decision analysis based on well-conducted } \\
\text { studies }\end{array}$} \\
\hline \multicolumn{2}{|l|}{ Level 2} \\
\hline - Low-power randomised comparative studies & B \\
\hline $\begin{array}{l}\text { - Well-conducted non-randomised comparative } \\
\text { studies }\end{array}$ & $\begin{array}{l}\text { Scientific proof } \\
\text { presumed }\end{array}$ \\
\hline \multicolumn{2}{|l|}{ Level 3} \\
\hline \multicolumn{2}{|l|}{ - Case-control studies } \\
\hline & $\mathrm{C}$ \\
\hline Level 4 & Low level of proof \\
\hline \multicolumn{2}{|l|}{ - Comparative studies with major bias } \\
\hline \multicolumn{2}{|l|}{ - Retrospective studies } \\
\hline - Case series & \\
\hline
\end{tabular}

With regard to bladder cancer risk levels and the minimum exposure duration associated with a high risk of bladder cancer, when information was available, we agreed upon:

- a moderate relative risk for bladder cancer, for statistically significant relative risk (RR), odds ratio (OR) or standardised mortality ratio (SMR) observed in the scientific literature strictly above 1 and equal to or below 2;

- a high relative risk for bladder cancer for statistically significant RR, OR or SMR strictly above 2 and equal to or below 5;

- and a very high relative risk for bladder cancer for statistically significant RR, OR or SMR strictly above 5 .

Consulted bibliographical databases included: Medline (National Library of Medicine, USA), Cochrane Library (Wiley Interscience, USA), Pascal - Institut national de l'information scientifique et technique (National scientific and technical information institute, France), National Guideline Clearinghouse (Agency for Healthcare Research and Quality, USA), Guidelines Finder (National Library for Health, USA).

We also consulted a number of websites: INRS, InVS, HAS (French National Authority for Health), Lemanissier medical library, National Institute for Health and
Clinical Excellence, Scottish Intercollegiate Guidelines Network, The National Cancer Institute for Occupational Safety and Health (NIOSH) and the websites published by learned societies involved in the project.

We also used other sources of information: the bibliographical references quoted in analysed articles, recommendations (Canadian, German and American) on the screening of bladder cancer, the National Toxicology Program classification of chemical carcinogenic substances and the European Union of Dangerous Substances classification.

Concerning occupational risk factors, only publications in English and French were selected, all dating from 1950 to 1st September 2011, by using the following key words: "urinary bladder neoplasms", "bladder neoplasm", "bladder cancer", "bladder tumour", "occupational diseases", "occupation", "occupational exposure", "work", "latency", "natural history", "treatment", "sensitivity", specificity", "screening" and all key words concerning bladder carcinogens and activities potentially exposing to bladder carcinogens ("aromatic amines", "polycyclic aromatic hydrocarbons", "nitrosamines", "rubber industry", "dye industry", "tannery", "leather", "leather industry", "hairdressers", "chemical industry", "chemical plants", "laboratory", "research laboratory", "printing industry", "aluminium", "aluminium reduction plant", "aluminium production", "aluminium industry", "coal tar pitch", "Söderberg”, “foundry”, “steel”, “iron”, “tar”, "tar distillation", "distillery", "creosote", "calcium carbide", "coal gasification", "coal”, "gas workers", "shale oils", "carbon black”, "carbon”, "electrode”, "electrode manufacturing", "coke", "coke industry", "coke production", "roofer", "waterproofer", "bituminen”, "diesel”, "diesel exhausts", "diesel engine exhausts", "gasoline”, "gasoline engine exhausts", "paint”, “painter", "varnish" "lacquer”.). Concerning bladder cancer screening tests, we exclusively selected publications in English and French, all dating from 1990 to 1 st September 2011 by using, the key words: "screening", "urinary tests", "fluorescence immunocytochemistry urinary test", "urinary cytology", "NMP 22", "NMP22BC test", "Fluorescence In Situ Hybridisation", "FISH, "Fibrinogen Degradation Products", "Bladder Tumour Antigen", “cytokeratin", "fibroblast growth factor receptor", "microsatellites". A total of 2,278 references were obtained. The first selection of articles was based on the title and abstract to include only metaanalysis, systematic reviews, cohort studies which were "well-conducted" (i.e. taking into account confounding factors and potential dose-response relationships) and case-control studies for which occupational exposure was clearly described. A total of 682 articles was finally analysed. All consulted sources (except Canadian, German and American recommendations) contained peer-reviewed data. 
A working group of 23 members was created, comprising 4 members from the SFMT (French Society for Occupational Health) designated by their own society, 2 oncologists designated by the SFC (French Cancer Society), 3 urologists designated by the AFU (French Urology Association), one member from the INRS (French Research and Safety Institute), one member from the InVS (French Institute for Public Health Surveillance), occupational physicians, general practitioners, epidemiologists, a biologist, an anatomopathologist and members of patient associations.

The first draft of proposed recommendations was read by a reading group comprised of 87 healthcare professionals (1 member from the Direction Générale $d u$ Travail (General Directorate for Labour), 1 member from the Caisse Nationale d'Assurance Maladie des Travailleurs Salariés, Direction des Risques Professionnels (French health insurance fund for salaried workers - Professional risks directorate), 48 occupational physicians (medical practitioners, university hospital practitioners and screening institution practitioners), 5 work and labour inspection practitioners, 12 general practitioners, 9 urologists, 5 oncologists, 7 representatives from partner social institutions and 3 research and prevention engineers), with a response rate of $84.6 \%$. Readers were asked to critically comment the working group's argumentation and to grade their agreement with its formulated recommendations ( 1 in the case of total disagreement, 9 in the case of total agreement). The draft was therefore revised where appropriate by the working group according to readers' comments. The final version of the recommendation argumentation was analysed by the HAS good professional practice recommendation committee and the HAS scientific college.

Since no human being was involved in this study, no Ethics Committee or Institutional Review Board approval was necessary. For the same reason, no written informed consent was necessary.

\section{Results}

Table 2 and Table 3 summarise the results of analysis of the scientific literature concerning identification of carcinogenic risk groups (Table 2 defines categories of workers to be discussed for inclusion in a targeted bladder cancer screening programme. Table 3 defines categories of workers for whom high exposure to occupational bladder carcinogens has generally been established without specific published epidemiological studies on bladder cancer risk in these groups of workers). We have chosen to list the occupations or sectors of activity associated with increased bladder cancer risk, rather than the incriminated chemical agents, in order to render the table more suitable for use by occupational physicians (or general practitioners/urologists), when defining their medical surveillance strategy. As expected, risk level after analysis of the literature is very high with a high degree of proof for rubber industry workers and dye manufacturing workers. Risk level is high for plastics industry workers if exposed to 4,4'-methylene bis (chloroaniline) (MBOCA), for workers involved in the production of 4-chloro-orthotoluidine-based pesticides, but also for textile industry (dyeing) workers and for leather and tanning industry workers. Moderate risk levels are observed for many occupations, such as hairdressers and assimilated professions, workers exposed to coal combustion soot or painters. Surprisingly, for certain workers, such as road surfacing workers, workers using coal-tar creosotes, calcium carbide production workers, shale oil extraction workers or coke manufacturing workers, there was insufficient data to establish risk level after analysis of the literature, even if high exposure to occupational bladder carcinogens has generally been established for these workers.

Table 4 summarises the results of the performance of proposed and marketed urinary tests for diagnosing bladder cancer, their availability, acceptability, adverse effects and cost. In this table, data including confidence intervals for sensitivity and specificity of urinary cytology, FISH, ImmunoCyt and NMP22 for the detection and follow-up of bladder cancer, result from a systematic review conducted in 2010 by the National Institute for Health Research (NIHR), and published as part of its Health Technology Assessment (HTA) programme [189]. Among the marketed urinary tests likely to be used in targeted bladder cancer screening, the fluorescence immunocytochemistry urinary test is the one that offers the best sensitivity all tumour stages and grades combined (evaluated at 84\% [IC 95\%, 77-91]) [189], whereas urinary cytology offers the best specificity all tumour stages and grades combined (above 90\%) [189-197].

In studies focusing on the sensitivity and the specificity of the urinary tests used combined, sensitivity is above that of any one test used alone (whereas specificity is, of course, lower than that of one test used alone). The combination of urinary cytology and fluorescence immunocytochemistry considerably increases sensitivity (mean: $85 \%$ ), compared to urinary cytology alone, in particular for the detection of low-grade tumours. The average specificity of the two tests combined is $70 \%[192,195,197,209]$.

The high cost of fluorescence immunocytochemistry and its limited availability (laboratory tests cannot be used during medical consultations and are performed by only a few French laboratories) mean that it is not the choice test for monitoring bladder carcinogen-exposed workers within a context of targeted screening of bladder cancer of occupational origin.

We conducted performance simulations for the different screening tests proposed (and combinations thereof), on a population of 100,000 male subjects aged from 50 
Targeted occupational group Position $\quad$ Level of risk after analysis

of the literature*

Rubber industry workers (level of proof 1) - rubber production workers, using 4-aminobiphenyl

the literature

VERY HIGH

Principle exposing positions in rubber and tyre manufacturing include weighing and mixing, finishing and storage, baking or vulcanisation exposing workers to PAHs and nitrosamines.

Dye manufacturing workers (level of proof 1) $[28-46]$

Textile industry (dyeing) workers (level of proof 3 to 4) [47-50]

Leather and tanning industry workers (level of proof 3) [51-56]

Targeted occupational group (main references)

Plastics industry workers, if exposed to 4,4'-methylene bis (chloroaniline) (MBOCA) [57-69]

Workers involved in the production of 4-chloro-ortho-toluidine-based pesticides (level of proof 2) [70]

Workers involved in aluminium production (level of proof 1) [71-89]

- workers in the production of benzidine and/or benzidine-derived and/or auramine-derived and/or ortho-toluidine-derived and/or magenta-derived and/or o-dianisidine-derived and/or o-tolidine-derived and/or o-dianisidine-derived and/or o-tolidine-derived and/or methylaniline-derived colouring agents

- subjects working in production workshops where the aforementioned products are used

Principle exposing activities include: preparation and weighing activities; pigment, colouring agent, paint and varnish manufacturing; quality control, sampling, laboratory and cleaning positions.

- yarn dyed fabric workers

- leather shoe and/or boot repair workers - tanning, leather goods, leather processing workers Position

-workers using epoxy and polyurethane resin hardening agents

- subjects working in workshops where epoxy and polyurethane resin hardening agents are used

- chlordimeform production workers

- subjects working in workshops where chlordimeform has been produced

aluminium production workers having used the Søderberg process
Before 1986

- workers weaving fibre into fabric

$$
\text { benzidine }
$$
ortho-toluidine

\section{Before 1970}

Before 1990
Level of risk after analysis of the literature*

$\mathrm{HIGH}$

Period of exposure

Since the 1950s and still in use today
Before 2003

Generally before 1989

Before 1950 for subjects exclusively exposed to $\beta$-naphtylamine and its salts

Before 1970 for subjects exclusively exposed to 4-aminobiphenyl

However: harmful residual carcinogenic substances (PAHs and nitrosamines in particular) remained in use in the rubber industry beyond the 1980s.

Generally before 1989

Before 1980 for subjects exclusively exposed to

Before 1990 for subjects exclusively exposed to

However: harmful residual carcinogenic substances PAHs and nitrosamines in particular) remained in use in the textile dyeing industry beyond the 1970s. 
Table 2 Worker categories to be discussed for inclusion in a targeted bladder cancer screening programme (Continued)

Textile industry (weaving) workers (level of

proof 2 to 3) [47-50]

Hairdressers and assimilated professions

(level of proof 2) [90-98]

- hairdressers

MODERATE

Before 1980

Workers involved in the plastics industry in

- barbers

- beauticians

general [57-69]

Chemical and pharmaceutical industry

workers [99-107]

Printing industry workers [108-111]

Targeted occupational group (main

references)

Iron and/or steel foundry workers [112-120]

Workers exposed to coal combustion soot $[95,121]$

-production agents (after detailed assessment of specific exposure to carcinogenic agents, PAHs in particular)

-production agents (after detailed assessment of

specific exposure to carcinogenic agents)

- ink manufacturing

- printers

Position

- iron and/or steel production workers (casting and/or knockout in particular)

- chimney sweeps

- coal fire boiler room workers and those having manufactured coal nuts

- coal gas production workers

To the present day

MODERATE

To the present day

MODERATE

Before 1970

evel of risk after analysis

of the literature*

Period of exposure

MODERATE

To the present day

MODERATE

To the present day

Before 2007

MODERATE

Before 1970

[122-124]

Roof waterproofing work [125-128]

- roofers

MODERATE

To the present day

- waterproofing workers

Workers exposed to diesel engine exhaust fumes [129-132]

- professional diesel engine vehicle drivers: (heavygoods vehicle drivers, public transport drivers, taxi drivers, work site vehicle drivers, diesel locomotive

drivers)

- motor vehicle mechanics

- automobile control technicians (MOT/inspection)

- 2-wheeled vehicle delivery drivers

- police officers

- tollbooth attendants

Metalworkers or fitters exposed to cutting oils and fluids [133-140]

- metal machining workers

- tool-dressers

- adjusters (tasks: machining, cutting, welding degreasing, maintenance/trimming) 
Table 2 Worker categories to be discussed for inclusion in a targeted bladder cancer screening programme (Continued)

\begin{tabular}{|c|c|c|c|}
\hline \multirow{2}{*}{$\begin{array}{l}\text { Transport vehicle repair and construction } \\
{[95,139,150,151]}\end{array}$} & - tool-dressers & \multirow[t]{2}{*}{ MODERATE } & \multirow[t]{2}{*}{ To the present day } \\
\hline & - adjusters & & \\
\hline Dry cleaning workers [152-159] & dry cleaning workers & MODERATE & To the present day \\
\hline Wine growers [160] & - use of arsenic-based pesticides & MODERATE & Before 2001 \\
\hline
\end{tabular}

- use of arsenic-based pesticides $\quad$ MODERATE $\quad$ Before 2001

* VERY HIGH relative risk for relative risks (RR), Odds ratios (OR) or Standardised Mortality Ratios (SMR) observed in the scientific literature strictly above 5; HIGH relative risk for RR, OR or SMR strictly above 2 and equal to or below 5 and MODERATE relative risk for RR, OR or SMR strictly above 1 and equal to or below 2. 
Table 3 Categories of workers for whom high exposure to occupational bladder carcinogens has generally been established without specific epidemiological studies on the risk of bladder cancer in these groups of workers

\begin{tabular}{|c|c|c|c|}
\hline $\begin{array}{l}\text { Targeted occupational group } \\
\text { (main references) }\end{array}$ & Position & $\begin{array}{l}\text { Level of risk after analysis of } \\
\text { the literature* }\end{array}$ & Period of exposure \\
\hline Research laboratory workers [161-167] & $\begin{array}{l}\text { Genetic engineering, nuclear biology, } \\
\text { mutagenesis and cancerogenesis } \\
\text { laboratories, weighing activities, use of } \\
\text { reagents and synthetic intermediates* }\end{array}$ & $\begin{array}{l}\text { Insufficient data to establish } \\
\text { risk level }\end{array}$ & To the present day \\
\hline Road surfacing workers [125-128] & Asphalt spreaders, gritters, compactors & $\begin{array}{l}\text { Insufficient data to establish } \\
\text { risk level }\end{array}$ & Up to the late 1980s \\
\hline $\begin{array}{l}\text { Workers using coal-tar creosotes } \\
{[112,168-170]}\end{array}$ & $\begin{array}{l}\text { Workers conducting specific wood } \\
\text { treatment activities }\end{array}$ & $\begin{array}{l}\text { Insufficient data to establish } \\
\text { risk level }\end{array}$ & To the present day \\
\hline Calcium carbide production workers [171] & Production workers* & $\begin{array}{l}\text { Insufficient data to establish } \\
\text { risk level }\end{array}$ & Up to the mid 2000s \\
\hline Shale oil extraction workers [172] & Shale oil extraction workers & $\begin{array}{l}\text { Insufficient data to establish } \\
\text { risk level }\end{array}$ & To the present day \\
\hline $\begin{array}{l}\text { Carbon black production workers } \\
{[50,173-176]}\end{array}$ & Manufacturing workers* & $\begin{array}{l}\text { Insufficient data to establish } \\
\text { risk level }\end{array}$ & To the present day \\
\hline $\begin{array}{l}\text { Carbon electrode manufacturing workers } \\
{[177-179]}\end{array}$ & Manufacturing workers* & $\begin{array}{l}\text { Insufficient data to establish } \\
\text { risk level }\end{array}$ & To the present day \\
\hline $\begin{array}{l}\text { Coke manufacturing workers } \\
{[125-128,180-186]}\end{array}$ & Cokers & $\begin{array}{l}\text { Insufficient data to establish } \\
\text { risk level }\end{array}$ & To the present day \\
\hline Carbon nut industry [187] & Manufacturing workers* & $\begin{array}{l}\text { Insufficient data to establish } \\
\text { risk level }\end{array}$ & To the present day \\
\hline Carbon disc manufacturing [188] & $\begin{array}{l}\text { Manufacturing* and } \\
\text { maintenance workers }\end{array}$ & $\begin{array}{l}\text { Insufficient data to establish } \\
\text { risk level }\end{array}$ & To the present day \\
\hline Clay pigeon manufacturing [188] & Manufacturing workers* & $\begin{array}{l}\text { Insufficient data to establish } \\
\text { risk level }\end{array}$ & To the present day \\
\hline Cement oven repair [188] & Manufacturing workers* & $\begin{array}{l}\text { Insufficient data to establish } \\
\text { risk level }\end{array}$ & To the present day \\
\hline $\begin{array}{l}\text { Work on water conveyance conducts } \\
\text { coated with varnish containing HAP [188] }\end{array}$ & Technicians/repair workers* & $\begin{array}{l}\text { Insufficient data to establish } \\
\text { risk level }\end{array}$ & To the present day \\
\hline Glazing in aluminium foundries [188] & Glazers & $\begin{array}{l}\text { Insufficient data to establish } \\
\text { risk level }\end{array}$ & To the present day \\
\hline
\end{tabular}

*After detailed assessment of specific exposure to carcinogenic agents.

Table 4 Proposed and marketed urinary tests for bladder cancer screening: summary of performance, availability, acceptability, adverse effects

\begin{tabular}{|c|c|c|c|}
\hline Test/dosage & Sensitivity & Specificity & Main references \\
\hline $\begin{array}{l}\text { Detection of haematuria using a } \\
\text { reactive test strip }\end{array}$ & $\begin{array}{l}46 \text { to } 74 \% \text { for one test, If test repeated } \\
\text { over several days: } 90 \text { to } 95 \%\end{array}$ & 51 to $84 \%$ & {$[190,198-202]$} \\
\hline \multirow[t]{2}{*}{ Urinary cytology } & $\begin{array}{l}\text { - For all tumour grades and stages: } 44 \% \\
\text { [CI 95\%, 38-51] [203] }\end{array}$ & $\begin{array}{l}\text { - For all tumour grades and stages: } \\
\mathbf{9 6 \%}[\mathbf{C l} \mathbf{9 5 \% , 9 4 - 9 8 ] ~ [ 2 0 3 ]}\end{array}$ & {$[191-197,203,204]$} \\
\hline & - For Carcinoma in situ (Cis) 70 to $90 \%$ & - For Cis: $90 \%$ & \\
\hline \multirow[t]{5}{*}{ NMP22BC test } & $\begin{array}{l}\text { - For all tumour grades and stages: 65\% } \\
\text { [CI 95\%, 50-80] [203] }\end{array}$ & $\begin{array}{l}\text { - For all tumour grades and stages: } \\
81 \% \text { [Cl 95\%, 50-85] [203] }\end{array}$ & {$[197,203-209]$} \\
\hline & - NMIBC: $81.8 \%$ & & \\
\hline & - MIBC: $57.1 \%$ & & \\
\hline & - Grade G1: $83.9 \%$ & & \\
\hline & - Grade G3: 62.5\% & & \\
\hline $\begin{array}{l}\text { Fluorescence immunocytochemistry } \\
\left(\text { ImmunoCyt } t^{\mathrm{TM}} / \mathrm{u} C y \mathrm{t}+{ }^{\mathrm{TM}}\right)\end{array}$ & $\begin{array}{l}\text { - For all tumour grades and stages: 84\% } \\
\text { [CI 95\%, 77-91] [203] }\end{array}$ & $\begin{array}{l}\text { - For all tumour grades and stages: } \\
\text { 75\% [CI 95\%, 68-83] [203] }\end{array}$ & {$[189,203,210-213]$} \\
\hline \multirow[t]{2}{*}{$\begin{array}{l}\text { FISH (Fluorescence In Situ } \\
\text { Hybridisation) UroVysion }{ }^{T m} \text { Kit }\end{array}$} & $\begin{array}{l}\text { - For all tumour grades and stages: } 76 \% \\
\text { [Cl 95\%, 65-84] [203] }\end{array}$ & $\begin{array}{l}\text { - For all tumour grades and stages: } \\
75 \% \text { [Cl 95\%, 78-92] [203] }\end{array}$ & {$[189,191,192,203,214-218$} \\
\hline & - For $\mathrm{Cis}$ and $\mathrm{G3}:>\mathbf{9 5 \%}$ & & \\
\hline
\end{tabular}


to 74 years, based on their degree of exposure to bladder carcinogens (refer to Additional file 1: Table S1). Bladder cancer incidence in this population was 54.6 cases/ 100,000 . In the absence of sufficient data, the sensitivity and specificity of test combinations were calculated as if the test had been conducted independently. The NMP22BC test, exclusive haematuria testing and combinations of urine cytology with, respectively, the NMP22BC test and haematuria test, generated an extremely high proportion of false positive results (around 20,000 false positives for 100,000 subjects, in each high-risk group category). If we extrapolate these results to a population of 750,000 subjects concerned by potential targeted screening in France (subjects at a high and very high risk of bladder cancer), the number of false positives likely to be generated by these tests would be 300,000 . Urinary cytology used alone would generate 8,000 false positives for 100,000 high or very high risk subjects which, in our population of 750,000 subjects, corresponds to 60,000 false positive results. Although very high, this figure is well below the 300,000 observed with the previously described tests.

The sensitivity of urinary cytology alone is mediocre all stages combined (mean: 44\%, see Table 4), hence generating a large number of false negatives. Nevertheless, the sensitivity of this technique is the best for high grades (mean: $80 \%$, see Table 4), which require early diagnosis since late-stage cancers are of very poor prognosis, hence rendering it the choice option for first line targeted screening strategies.

\section{Discussion}

In 2005, a panel of international experts (International Consensus Panel on cytology and bladder tumour markers) concluded that individual screening in high-risk patients (smokers, occupationally-exposed subjects, subjects with a genetic predisposition) could be considered using, in particular, urinary makers associated or not with conventional cytology. In this indication, although no currently marketed tumour markers appear suitable for replacing cytoscopy, tests such as fluorescence immunocytochemistry, combined with cytology, microsatellites or FISH (Fluorescence In Situ Hybridisation) are of genuine interest, offering high sensitivity and a negative predictive value of $95 \%$, hence avoiding unnecessary cytoscopies [13].

The main diagnostic limitation of urinary markers is their specificity, which is lower than that of conventional cytology and behind a substantial number of false positive results; they are also costly. In certain studies, the performance of the various tests likely to be used for bladder cancer screening were compared on the same patient: for each comparison, urinary cytology offered lower sensitivity, all grades combined, than the marker with which it was compared, whilst offering higher sensitivity for high-grade tumours and higher specificity whatever the grade.

Since several studies on bladder cancer screening tools are currently underway, the present recommendations will require to be reassessed according to results of new and ongoing studies.

The various aforementioned observations led the French team to put forward the following recommendations:

- The high cost of fluorescence immunocytochemistry and its limited availability (laboratory tests cannot be used during medical consultations and are performed by only a few French laboratories) mean that it is not the choice test for monitoring bladder carcinogen-exposed workers within a context of targeted screening of bladder cancer of occupational origin.

- Given its poor performance, in terms of both sensitivity and specificity, it is recommended to avoid the exclusive detection of microscopic haematuria using reactive urinary test strips during specific follow-up consultations for targeted screening of subjects currently or previously occupationally exposed to carcinogens.

- Repeated detection of microscopic haematuria using reactive urinary strips (daily test over 5 days, then weekly test over 51 weeks or daily test over 14 days then, in the absence of haematuria, daily test over 14 days - 9 months later) offers good sensitivity [194]. However, the constraints involved in its implementation (urinary strip packaging, uncertainty on user compliance) do not enable it to be considered as a choice examination within the context of the follow-up of workers exposed to bladder carcinogens for the targeted screening of bladder cancer of occupational origin.

- Urinary cytology (or urinary cytodiagnosis), the aim of which is to detect tumour cells originating from bladder or urinary tract cancer and desquamating in urine, is the urinary test with the best specificity (for all tumour grades and stages - on average, above $90 \%$, see Table 4), and with the best sensitivity for high-grade tumours, requiring urgent medical care, hence its first-line use.

- According to current knowledge, the combination of urinary cytology and urinary tests such as the NMP22BC test cannot be recommended within targeted screening procedures.

\section{Proposal for the medical follow-up of workers currently or previously exposed to bladder carcinogens} In populations presenting with a high risk of bladder cancer subsequent to occupational exposure justifying 
targeted screening, screening tests are recommended 20 years after the start of exposure to the bladder carcinogen (GRADE B recommendation, "Scientific proof presumed").

Urinary cytology among subjects currently or previously exposed to bladder carcinogens is recommended for subjects included in a targeted screening programme (expert consensus).

A 6-month periodicity is recommended for conducting targeted bladder cancer screening tests among subjects currently or previously occupationally exposed to bladder carcinogens (expert consensus).

The proposed medical surveillance protocol accounts for the performance of the various screening tests (specificity/sensitivity) and, in particular, the expected number of false positive results for the monitored population. This protocol is summarised in the following algorithm (Table 5) (expert consensus):

- RECOMMENDED (in all cases): for groups of workers with a very high risk of bladder cancer i.e. $R R>5$ (see Table 2), or professions with documented high exposure levels (Table 3), with an exposure duration equal to or in excess of 1 year;

- PROPOSED (for discussion on a case-by-case basis):

- for groups of workers with a very high risk of bladder cancer (see Table 2) or professions with documented high exposure levels (Table 3), with an exposure duration of less than 1 year;

- for groups of workers with a high risk of bladder cancer (Table 2) with an exposure duration equal to or in excess of 1 year;

- NOT RECOMMENDED (in view of the performance of currently available tests) for groups of workers with a moderate risk of bladder cancer (Table 2), and for groups of workers with a high risk of bladder cancer (Table 2), with an exposure duration of less than 1 year.
Subsequent to the compilation of these recommendations, a few new articles have been published [219]. Indeed, authors analysed the performance of FISH (Fluorescence In Situ Hybridisation) in combination with NMP22 for bladder cancer screening in this population. They observed that the combination of these 2 tests detected more cases than cytology alone, at the expense of a lower specificity, and concluded that it cannot be recommended to apply these markers for screening in asymptomatic workers, given that the increase in sensitivity is not balanced by the high cost of FISH and the false-positive results obtained by NMP 22 . Another recent study on occupational urinary tract cancers in Great Britain described the same types of occupational exposure associated with bladder cancer as those compiled in our own study [220].

\section{Conclusion}

Occupational cancer prevention relies first and foremost on primary prevention, in other words, not only the identification of carcinogenic substances present in the working environment, but also on the evaluation of individual and collective exposure, hence enabling the implementation of measures aimed at eliminating/controlling these substances. Such prevention implies accurate risk assessment, taking into account current scientific knowledge on modes of action, dose-effect relationships and on the potential existence of an effect threshold, in order to enable the reduction and the traceability of occupational exposure. Such traceability must offer workers the benefits of improved knowledge in terms of information on toxicity and medical follow-up. Certain authors have even established a guideline to assess occupational bladder cancer risk. For example, a German research group has provided a multilingual questionnaire on occupational and further bladder cancer risk factors [221]. This questionnaire asks for relevant medical information, for the occupational history since leaving school and for intensity and frequency of certain occupational and non-occupational risk factors. In another study, the authors established a guideline specifically evaluating occupational bladder cancer risk for compensation [222].

Table 5 Algorithm summarising the recommended medico-professional follow-up of workers currently or previously exposed to carcinogenic substances for the bladder

\begin{tabular}{|c|c|c|c|c|c|}
\hline \multirow{2}{*}{$\begin{array}{l}\text { Risk level for the professional group } \\
\text { Exposure duration }\end{array}$} & \multicolumn{2}{|c|}{$\begin{array}{c}\text { Group of workers with a VERY } \\
\text { HIGH risk (RR or OR or SMR }>5 \text { ) } \\
\text { or professions with documented } \\
\text { high exposure levels }\end{array}$} & \multicolumn{2}{|c|}{$\begin{array}{c}\text { Group of workers with } \\
\text { a HIGH risk }(2<\text { RR or } \\
\text { OR or SMR } \leq 5)\end{array}$} & \multirow[t]{2}{*}{$\begin{array}{l}\text { Group of workers with } \\
\text { a MODERATE risk } \\
(1<\text { RR or OR or SMR } \leq 2)\end{array}$} \\
\hline & $\geq 1$ year & $<1$ year & $\geq 1$ year & $<1$ year & \\
\hline Follow-up & RECOMMENDED & \multicolumn{2}{|c|}{ PROPOSED } & $\begin{array}{l}\text { NOT REC } \\
\text { performanc }\end{array}$ & $\begin{array}{l}\text { MMENDED (in view of the } \\
\text { of currently available tests) }\end{array}$ \\
\hline mum latency period after the start of exposure & \multicolumn{5}{|c|}{20 years } \\
\hline Proposed first line, then 6-monthly test & \multicolumn{5}{|c|}{ Urinary cytology } \\
\hline
\end{tabular}


Even if no study has relied on a sufficient sample of individuals to assess the relevance of bladder cancer screening in populations at risk, we are convinced of the necessity to implement recommendations that rely on analysis of the scientific literature to provide a more rational definition of medical surveillance modalities for subjects currently or previously exposed to bladder carcinogens.

Nevertheless, an evaluation of the benefits of this targeted screening strategy for bladder cancer is recommended. Given ongoing research on the different urinary markers for potential use in targeted bladder cancer screening, analysis of the feasibility and the performance of a targeted bladder screening programme combining urinary cytology and other urinary markers is recommended within a 5-year timescale.

\section{Additional file}

Additional file 1: Table S1. Simulated performance of proposed

screening tests (and combinations).

\section{Competing interest}

The authors declare that they have no competing interests, or other interests that might be perceived to influence the results and discussion reported in this paper.

\section{Authors' contributions}

$\mathrm{BC}$ has made the bibliographic analysis and drafted the manuscript; members of the "RecoCancerProf" Working participated to the bibliographic analysis; JCP has been involved in drafting the manuscript and revised it critically. All authors read and approved the final manuscript.

\section{Authors' information}

"RecoCancerProf" Working Group: *Yves ALLORY, Service d'Anatomie Pathologique, Centre Hospitalier Henri Mondor, Créteil (94)

(yves.allory@hmn.aphp.fr), Jérôme BEAUJARD, La Fare les Oliviers (13), (Jerome.BEAUJARD@wanadoo.fr), Dominique BESSETTE, INCa, Boulogne (92) (dbessette@institutcancer.fr), Patrick BROCHARD, Service de Santé au Travail et Pathologie Professionnelle, Centre Hospitalier de Bordeaux (33) (patrick. brochard@chu-bordeaux.fr), Michèle CHATAIGNIER, pour I'Association des Accidentés de la Vie, Bressuire (79) (michele.erisse@orange.fr), Jacqueline CLAVEL, Institut national de la santé et de la recherche médicale (INSERM), Villejuif (94) (jacqueline.clavel@inserm.fr), Françoise CONSO, Membre de la SFMT, Paris (75) (francoise.conso@parisdescartes.fr), Françoise FAUPIN, Suresnes (92) (Francoise.faupin@acms.asso.fr), Jean-François GEHANNO, Service de médecine et santé au travail, Centre Hospitalier de Rouen (76) (JF.Gehanno@chu-rouen.fr), Philippe GRIPON, Renault Trucks, Blainville sur Orne (14) (Philippe.gripon@renault-trucks.com), Marine GROSS-GOUPIL, Service d'oncologie, Centre Hospitalier de Bordeaux (33) (marine.grossgoupil@chu-bordeaux.fr), Laurent GUY, Service d'urologie, Hôpital G. Montpied, Clermont-Ferrand (63) (lguy@chu-clermontferrand.fr), Michel HERY, INRS, Vandœuvre (54) (michel.hery@inrs.fr), Nadine HOUEDE, Service d'Oncologie, Institut Bergonié, Bordeaux (33) (houede@bergonie.org), Ellen IMBERNON, InVS, Saint-Maurice (94) (e.imbernon@invs.sante.fr), Danièle LUCE, InVS, Saint-Maurice (94) (daniele.luce@inserm.fr), Christophe PARIS, Service de médecine et santé au travail, membre de la SFMT, Centre Hospitalier de Nancy (54) (christophe.paris@inserm.fr), Christian PFISTER, Service d'Urologie, Centre Hospitalier de Rouen (76) (christian.pfister@chu-rouen.fr), François RADVANYI, Service de Biologie, Centre Hospitalier Henri Mondor, Créteil (94) (Francois.Radvanyi@curie.fr), Alain RAVAUD, Service d'Oncologie, membre de la SFC, Centre Hospitalier de Bordeaux (33) (alain.ravaud@chu-bordeaux.fr), Morgan ROUPRET, Service d'Urologie, Hôpital Pitié-Salpétrière (AP-HP), Université Pierre et Marie Curie, Paris (75) (mroupret@gmail.com), Marcel
RUETSCH, Dessenheim (68) (dr.m.ruetsch.mg@wanadoo.fr) and Marie-Paule VIGOUROUX, pour la Ligue Nationale contre le cancer, Plescop (56) (mpvigx@wanadoo.fr).

\section{Acknowledgements}

The authors would like to thank the SFMT (French Society for Occupational Health), the SFC (French Cancer Society), the AFU (French Urology Association), the INRS (National Research and Safety Institute), the InVS (French Institute for Public Health Surveillance) and all the members of the working group and the reading group.

The authors are also indebted to Doctor Muriel DHENAIN, methodologist at the HAS.

\section{Grant support}

This study has received financial support from the Direction Générale du Travail (DGT).

\section{Author details}

${ }^{1}$ Cancers and prevention, U1086 INSERM, Faculty of Medicine, Caen University Hospital, Caen, France. ${ }^{2}$ Service de Santé au Travail et Pathologie Professionnelle (Occupational Health Department), C.H.U. (University Hospital) Côte de Nacre, 14033 CAEN Cedex, France. ${ }^{3}$ INSERM, Unité 955, Université Paris-Est Créteil, 94000 Créteil, France. ${ }^{4}$ Centre Hospitalier Intercommunal de Créteil, Service de Pneumologie et de Pathologie Professionnelle, 94000 Créteil, France.

Received: 1 February 2014 Accepted: 17 October 2014 Published: 6 November 2014

\section{References}

1. Jemal A, Bray F, Center MM, Ferlay J, Ward E, Forman D: Global cancer statistics. CA Cancer J Clin 2011, 61:69-90.

2. Ploeg M, Aben KK, Kiemeney LA: The present and future burden of urinary bladder cancer in the world. World J Urol 2009, 27:289-93.

3. InVS: Projection de l'incidence et de la mortalité par cancer en France en 2011. InVS, http://www.invs.sante.fr.

4. Binder-Foucard F, Belot A, Delafosse P, Remontet L, Woronoff A-S, Bossard $\mathrm{N}$ : Estimation nationale de l'incidence et de la mortalité par cancer en France entre 1980 et 2012. Partie 1 - Tumeurs solides. Saint-Maurice (Fra): Institut de veille sanitaire: 2013:122.

5. Vineis $P$, Simonato $L$ : Proportion of lung and bladder cancers in males resulting from occupation: a systematic approach. Arch Environ Health 1991, 46:6-15

6. Bang KM: Epidemiology of occupational cancer. Occup Med 1996, 11:467-85.

7. Nurminen M, Karjalainen A: Epidemiologic estimate of the proportion of fatalities related to occupational factors in Finland. Scand J Work Environ Health 2001, 27:161-213.

8. Imbernon E: Estimation du nombre de cas de certains cancers attribuables à des facteurs professionnels en France. Institut de Veille Sanitaire, SaintMaurice; 2003:28.

9. Yamaguchi N, Tazaki H, Okubo T, Toyama T: Periodic urine cytology surveillance of bladder tumor incidence in dyestuff workers. Am J Ind Med 1982, 3:139-48.

10. Mazeman E: Tumors of the upper excretory urinary tract, calices, renal pelvis and ureter. J Urol Nephrol 1972, 78(Suppl 9):1-219.

11. Jemal A, Siegel R, Ward E, Hao Y, Xu J, Thun MJ: Cancer statistics, 2009. CA Cancer J Clin 2009, 59:225-49.

12. US Preventive Task Force: Screening for bladder cancer in adults: recommendation statement 2004. http://www.uspreventiveservices taskforce.org/uspstf/uspsblad.htm.

13. Lokeshwar VB, Habuchi T, Grossman HB, Murphy WM, Hautmann SH, Hemstreet GP 3rd, Bono AV, Getzenberg RH, Goebell P, Schmitz-Dräger BJ, Schalken JA, Fradet Y, Marberger M, Messing E, Droller MJ: Bladder tumor markers beyond cytology: international consensus panel on bladder tumor markers. Urology 2005, 66(6 Suppl 1):35-63.

14. IARC Working Group on the Evaluation of Carcinogenic Risks to Humans: The Rubber Industry, Volume 28. Lyon: IARC; 1982:486.

15. Lakshmi VM, Hsu FF, Zenser TV: Transformation and activation of benzidine by oxidants of the inflammatory response. Chem Res Toxico 2003, 16:367-74. 
16. Beyerbach A, Rothman N, Bhatnagar VK, Kashyap R, Sabbioni G: Hemoglobin adducts in workers exposed to benzidine and azo dyes. Carcinogenesis 2006, 27:1600-6.

17. Melick WF, Escue HM, Naryka JJ, Mezera RA, Wheeler EP: The first reported cases of human bladder tumors due to a new carcinogen-xenylamine. J Urol 1955, 74:760-6.

18. Melick WF, Naryka JJ, Kelly RE: Bladder cancer due to exposure to para-aminobiphenyl: a 17-year followup. J Urol 1971, 106:220-6.

19. Collins JJ, Strauss ME, Riordan SG: Mortalities of workers at the Nitro plant with exposure to 2-mercaptobenzothialzole. Occup Environ Med 1999, 56:667-71.

20. Veys CA: Two epidemiological inquiries into the incidence of bladder tumors in industrial workers. J Natl Cancer Inst 1969, 43:219-26.

21. Veys CA: Bladder tumours in rubber workers: a factory study 1946-1995. Occup Med (Lond) 2004, 54:322-9.

22. Morinaga K, Oshima A, Hara I: Multiple primary cancers following exposure to benzidine and beta-naphthylamine. Am J Ind Med 1982 3:243-6.

23. Naito S, Tanaka K, Koga H, Kotoh S, Hirohata T, Kumazawa J: Cancer occurrence among dyestuff workers exposed to aromatic amines. A long term follow-up study. Cancer 1995, 76:1445-52.

24. Cassidy LD, Youk AO, Marsh GM: The drake health registry study: cause-specific mortality experience of workers potentially exposed to beta-naphthylamine. Am J Ind Med 2003, 44:282-90.

25. Sorahan T, Hamilton L, Jackson JR: A further cohort study of workers employed at a factory manufacturing chemicals for the rubber industry, with special reference to the chemicals 2-mercaptobenzothiazole (MBT), aniline, phenyl-beta-naphthylamine and o-toluidine. Occup Environ Med 2000, 57:106-15.

26. Kogevinas M, Sala M, Boffetta P, Kazerouni N, Kromhout H, Hoar-Zahm S: Cancer risk in the rubber industry: a review of the recent epidemiological evidence. Occup Environ Med 1998, 55:1-12.

27. Weiland SK, Mundt KA, Keil U, Kraemer B, Birk T, Person M, Bucher AM, Straif K, Schumann J, Chambless L: Cancer mortality among workers in the German rubber industry: 1981-91. Occup Environ Med 1996, 53(5):289-98.

28. Mancuso TF, El-Attar AA: Cohort study of workers exposed to betanaphthylamine and benzidine. J Occup Med 1967, 9(6):277-85.

29. Rubino GF, Scansetti G, Piolatto G, Pira E: The carcinogenic effect of aromatic amines: an epidemiological study on the role of o-toluidine and 4,4'-methylene bis (2-methylaniline) in inducing bladder cancer in man. Environ Res 1982, 27(2):241-54.

30. Decarli A, Peto J, Piolatto G, La Vecchia C: Bladder cancer mortality of workers exposed to aromatic amines: analysis of models of carcinogenesis. Br J Cancer 1985, 51(5):707-12

31. Bi W, Hayes RB, Feng P, Qi Y, You X, Zhen J, Zhang M, Qu B, Fu Z, Chen M: Mortality and incidence of bladder cancer in benzidine-exposed workers in China. Am J Ind Med 1992, 21(4):481-9.

32. Wu W: Occupational cancer epidemiology in the People's Republic of China. J Occup Med 1988, 30(12):968-74.

33. Szymczak W, Sitarek K, Baranski B: Mortality of workers in the dye industry. I. Analysis of general mortality. Med $\operatorname{Pr} 1995,46(5): 459-67$.

34. Sitarek K, Szymczak W, Baranski B: Mortality among the dye industry workers. II. An analysis of malignant neoplasm mortality. Med $\operatorname{Pr} 1995$ 46(5):469-77.

35. Rosenman KD, Reilly MJ: Cancer mortality and incidence among a cohort of benzidine and dichlorobenzidine dye manufacturing workers. Am J Ind Med 2004, 46(5):505-12.

36. Ugnat AM, Luo W, Semenciw R, Mao Y: Occupational exposure to chemical and petrochemical industries and bladder cancer risk in four western Canadian provinces. Chronic Dis Can 2004, 25(2):7-15.

37. Case RA, Pearson JT: Tumours of the urinary bladder in workmen engaged in the manufacture and use of certain dyestuff intermediates in the British chemical industry. II. Further consideration of the role of aniline and of the manufacture of auramine and magenta (fuchsine) as possible causative agents. Br J Ind Med 1954, 11(3):213-6.

38. Stasik MJ: Carcinomas of the urinary bladder in a 4-chloro-o-toluidine cohort. Int Arch Occup Environ Health 1988, 60(1):21-4.

39. Ward E, Carpenter A, Markowitz S, Roberts D, Halperin W: Excess number of bladder cancers in workers exposed to ortho-toluidine and aniline. $J \mathrm{Nat}$ Cancer Inst 1991, 83(7):501-6.
40. Ward EM, Sabbioni G, DeBord DG, Teass AW, Brown KK, Talaska GG, Roberts DR, Ruder AM, Streicher RP: Monitoring of aromatic amine exposures in workers at a chemical plant with a known bladder cancer excess. J Nat/ Cancer Inst 1996, 88(15):1046-52.

41. Viet S, Hanley K, Carreon-Valencia T, Viet S, Hanley K, Carreon-Valencia T: Assessment of exposure to o-toluidine and other aromatic amines in a rubber chemical manufacturing plant. NIOSH 2009. IWSB Report 73.

42. Prince MM, Ward EM, Ruder AM, Salvan A, Roberts DR: Mortality among rubber chemical manufacturing workers. Am J Ind Med 2000, 37:590-8.

43. Markowitz SB, Levin K: Continued epidemic of bladder cancer in workers exposed to ortho-toluidine in a chemical factory. J Occup Environ Med 2004, 46(2):154-60

44. Delzell E, Macaluso M, Cole P: A follow-up study of workers at a dye and resin manufacturing plant. J Occup Med 1989, 31(3):273-8.

45. Bulbulyan MA, Figgs LW, Zahm SH, Savitskaya T, Goldfarb A, Astashevsky S, Goldfarb A, Astashevsky S, Zaridze D: Cancer incidence and mortality among beta-naphthylamine and benzidine dye workers in Moscow. Int J Epidemiol 1995, 24(2):266-75.

46. Ott MG, Langner RR: A mortality survey of men engaged in the manufacture of organic dyes. J Occup Med 1983, 25(10):763-8.

47. IARC Working Group on the Evaluation of Carcinogenic Risks to Humans: Some Flame Retardants and Textile Chemicals, and Exposures in the Textile Manufacturing Industry, Volume 48. Lyon: IARC; 1990:38.

48. Gonzales CA, Riboli E, Lopez-Abente G: Bladder cancer among workers in the textile industry: results of a Spanish case-control study. Am J Ind Med 1988, 14:673-80.

49. Cordier S, Clavel J, Limasset JC, Boccon-Gibod L, Le Moual N, Mandereau L, Hemon D: Occupational risks of bladder cancer in France: a multicentre case-control study. Int J Epidemiol 1993, 22:403-11.

50. Sorahan T, Hamilton L, van Tongeren M, Gardiner K, Harrington JM: A cohort mortality study of U.K. carbon black workers, 1951-1996. Am J Ind Med 2001, 39:158-70.

51. Montanaro F, Ceppi M, Demers PA, Puntoni R, Bonassi S: Mortality in a cohort of tannery workers. Occup Environ Med 1997, 54(8):588-91.

52. Baxter PJ, McDowall ME: Occupation and cancer in London: an investigation into nasal and bladder cancer using the cancer atlas. Br J Ind Med 1986, 43(1):44-9.

53. Garabrant DH, Wegman DH: Cancer mortality among shoe and leather workers in Massachusetts. Am J Ind Med 1984, 5(4):303-14.

54. Cartwright RA, Boyko RW: Kidney cancer among leather workers. Lancet 1984, 1(8381):850-1.

55. Fu H, Demers PA, Costantini AS, Winter P, Colin D, Kogevinas M, Boffetta P: Cancer mortality among shoe manufacturing workers: an analysis of two cohorts. Occup Environ Med 1996, 53(6):394-8.

56. Costantini AS, Paci E, Miligi L, Buiatti E, Martelli C, Lenzi S: Cancer mortality among workers in the Tuscan tanning industry. $\mathrm{Br} J$ Ind Med 1989, 46(6):384-8.

57. Ward E, Halperin W, Thun M, Grossman HB, Fink B, Koss L, Osorio AM, Schulte $P$ : Bladder tumors in two young males occupationally exposed to MBOCA. Am J Ind Med 1988, 14(3):267-72.

58. Ward E, Halperin W, Thun M, Grossman HB, Fink B, Koss L, Osorio AM, Schulte P: Screening workers exposed to 4,4'-methylenebis(2-chloroaniline) for bladder cancer by cystoscopy. J Occup Med 1990, 32(9):865-8.

59. Hogan TJ: Case study "carcinogens:" the MBOCA TLV example. Am Ind Hyg Assoc J 1993, 54(8):458-60. discussion 61-3.

60. Mason TJ, Vogler WJ: Bladder cancer screening at the Dupont chambers works: a new initiative. J Occup Med 1990, 32(9):874-7.

61. Mason TJ, Walsh WP, Lee K, Vogler W: New opportunities for screening and early detection of bladder cancer. J Cell Biochem Suppl 1992, 161:13-22.

62. Chen HI, Liou SH, Loh CH, Uang SN, Yu YC, Shih TS: Bladder cancer screening and monitoring of 4,4'-methylenebis(2-chloroaniline) exposure among workers in Taiwan. Urology 2005, 66:305-10.

63. Liu CS, Liou SH, Loh CH, Yu YC, Uang SN, Shih TS, Chen HI: Occupational bladder cancer in a 4,4 -methylenebis(2-chloroaniline) (MBOCA)-exposed worker. Environ Health Perspect 2005, 113(6):771-4.

64. Claude J, Kunze E, Frentzel-Beyme R, Paczkowski K, Schneider J, Schubert H: Life-style and occupational risk factors in cancer of the lower urinary tract. Am J Epidemiol 1986, 124(4):578-89.

65. Claude JC, Frentzel-Beyme RR, Kunze E: Occupation and risk of cancer of the lower urinary tract among men. A case-control study. Int J Cancer 1988, 41(3):371-9. 
66. Kunze E, Chang-Claude J, Frentzel-Beyme R: Life style and occupational risk factors for bladder cancer in Germany. A case-control study. Cancer 1992, 69(7):1776-90.

67. Zheng W, McLaughlin JK, Gao YT, Silverman DT, Gao RN, Blot WJ: Bladder cancer and occupation in Shanghai, 1980-1984. Am J Ind Med 1992, 21(6):877-85.

68. Zahm SH, Hartge P, Hoover R: The national bladder cancer study: employment in the chemical industry. J Natl Cancer Inst 1987, 79(2):217-22.

69. La Vecchia C, Negri E, D'Avanzo B, Franceschi S: Occupation and the risk of bladder cancer. Int J Epidemiol 1990, 19(2):264-8.

70. Popp W, Schmieding W, Speck M, Vahrenholz C, Norpoth K: Incidence of bladder cancer in a cohort of workers exposed to 4-chloro-o-toluidine while synthesising chlordimeform. Br J Ind Med 1992, 49:529-31.

71. Wigle DT: Bladder cancer: possible new high-risk occupation. Lancet 1977, 2:83-4.

72. Theriault G, De Guire L, Cordier S: Reducing aluminum: an occupation possibly associated with bladder cancer. Can Med Assoc J 1981, 124(4):419. $-22,25$

73. Milham S Jr: Mortality in aluminum reduction plant workers. J Occup Med 1979, 21(7):475-80.

74. Gibbs GW, Horowitz I: Lung cancer mortality in aluminum reduction plant workers. J Occup Med 1979, 21(5):347-53.

75. Simonato L: Carcinogenic risk in the aluminium production industry: an epidemiological overview. Med Lav 1981, 72(4):266-76.

76. Gibbs GW: Mortality of aluminum reduction plant workers, 1950 through 1977. J Occup Med 1985, 27(10):761-70.

77. Theriault G, Tremblay C, Cordier S, Gingras S: Bladder cancer in the aluminium industry. Lancet 1984, 1(8383):947-50.

78. Armstrong BG, Tremblay CG, Cyr D, Theriault GP: Estimating the relationship between exposure to tar volatiles and the incidence of bladder cancer in aluminum smelter workers. Scand J Work Environ Health 1986, 12(5):486-93.

79. Tremblay C, Armstrong B, Theriault G, Brodeur J: Estimation of risk of developing bladder cancer among workers exposed to coal tar pitch volatiles in the primary aluminum industry. Am J Ind Med 1995, 27(3):335-48.

80. Andersen A, Dahlberg BE, Magnus K, Wannag A: Risk of cancer in the Norwegian aluminium industry. Int J Cancer 1982, 29(3):295-8.

81. Rockette HE, Arena VC: Mortality studies of aluminum reduction plant workers: potroom and carbon department. J Occup Med 1983, 25(7):549-57.

82. Mur JM, Moulin JJ, Meyer-Bisch C, Massin N, Coulon JP, Loulergue J: Mortality of aluminium reduction plant workers in France. Int J Epidemiol 1987, 16(2):257-64.

83. Moulin JJ, Clavel T, Buclez B, Laffitte-Rigaud G: A mortality study among workers in a French aluminium reduction plant. Int Arch Occup Environ Health 2000, 73(5):323-30.

84. Spinelli JJ, Band PR, Svirchev LM, Gallagher RP: Mortality and cancer incidence in aluminum reduction plant workers. J Occup Med 1991, 33(11):1150-5.

85. Romundstad P, Andersen A, Haldorsen T: Cancer incidence among workers in six Norwegian aluminum plants. Scand J Work Environ Health 2000, 26(6):461-9.

86. Ronneberg A, Andersen A: Mortality and cancer morbidity in workers from an aluminium smelter with prebaked carbon anodes-part II: cancer morbidity. Occup Environ Med 1995, 52(4):250-4.

87. Ronneberg A, Haldorsen T, Romundstad P, Andersen A: Occupational exposure and cancer incidence among workers from an aluminum smelter in western Norway. Scand J Work Environ Health 1999, 25(3):207-14.

88. Romundstad P, Haldorsen T, Andersen A: Lung and bladder cancer among workers in a Norwegian aluminium reduction plant. Occup Environ Med 2000, 57(7):495-9.

89. Romundstad P, Andersen A, Haldorsen T: Nonmalignant mortality among workers in six Norwegian aluminum plants. Scand J Work Environ Health 2000, 26(6):470-5.

90. IARC Working Group on the Evaluation of Carcinogenic Risks to Humans: Occupational Exposures of Hairdressers and Barbers and Personal use of Hair Colourants, Some Hair Dyes, Cosmetic Colourants, Industrial Dyestuffs and Aromatic Amines, Volume 57. Lyon: IARC; 1993:427.
91. Guberan E, Raymond L, Sweetnam PM: Increased risk for male bladder cancer among a cohort of male and female hairdressers from Geneva. Int J Epidemiol 1985, 14(4):549-54.

92. Harling M, Schablon A, Schedlbauer G, Dulon M, Nienhaus A: Bladder cancer among hairdressers: a meta-analysis. Occup Environ Med 2010, 67:351-8.

93. Takkouche B, Regueira-Mendez C, Montes-Martinez A: Risk of cancer among hairdressers and related workers: a meta-analysis. Int J Epidemiol 2009, 38:1512-31.

94. Lynge E: Occupational mortality and cancer analysis. Public Health Rev 1990, 18(2):99-116.

95. Andersen A, Barlow L, Engeland A, Kjaerheim K, Lynge E, Pukkala E: Work-related cancer in the Nordic countries. Scand J Work Environ Health 1999, 25(Suppl 2):1-116.

96. Czene K, Tiikkaja S, Hemminki K: Cancer risks in hairdressers: assessment of carcinogenicity of hair dyes and gels. Int J Cancer 2003, 105(1):108-12

97. Ji J, Granstrom C, Hemminki K: Occupation and bladder cancer: a cohort study in Sweden. Br J Cancer 2005, 92:1276-8.

98. Turesky RJ, Freeman JP, Holland RD, Nestorick DM, Miller DW, Ratnasinghe $\mathrm{DL}$, Kadlubar FF: Identification of aminobiphenyl derivatives in commercial hair dyes. Chem Res Toxicol 2003, 16(9):1162-73.

99. Teta MJ, Schnatter AR, Ott MG, Pell S: Mortality surveillance in a large chemical company: the Union Carbide Corporation experience, 1974-1983. Am J Ind Med 1990, 17(4):435-47.

100. Bond GG, Shellenberger RJ, Fishbeck WA, Cartmill JB, Lasich BJ, Wymer KT, Cook RR: Mortality among a large cohort of chemical manufacturing employees. J Natl Cancer Inst 1985, 75(5):859-69.

101. Burchfiel CM, Cartmill JB, Axe FD, Bond GG: General mortality and respiratory cancer among a cohort of male chemical workers in California. Am J Ind Med 1992, 22(1):69-83.

102. Pifer JW, Hearne FT, Friedlander BR, McDonough JR: Mortality study of men employed at a large chemical plant, 1972 through 1982. J Occup Med 1986, 28(6):438-44.

103. Hansen J, Olsen JH, Larsen Al: Cancer morbidity among employees in a Danish pharmaceutical plant. Int J Epidemiol 1994, 23(5):891-8.

104. Thomas TL, Decoufle P: Mortality among workers employed in the pharmaceutical industry: a preliminary investigation. J Occup Med 1979, 21(9):619-23.

105. Harrington JM, Goldblatt P: Census based mortality study of pharmaceutical industry workers. Br J Ind Med 1986, 43(3):206-11.

106. Edling C, Friis L, Mikoczy Z, Hagmar L, Lindfors P: Cancer incidence among pharmaceutical workers. Scand J Work Environ Health 1995, 21(2):116-23.

107. Davies JM, Thomas HF, Manson D: Bladder tumours among rodent operatives handling ANTU. Br Med J (Clin Res Ed) 1982, 285(6346):927-31.

108. Lafontaine M, Framboisier X, Morèle Y, Gendre J, Braud M, Ferrand C, Guillouzic JF: Risques chimiques liés à l'impression offset. Cahiers de notes documentaires 1996, 2033-165-96:475-80.

109. Bulbulyan MA, llychova SA, Zahm SH, Astashevsky SV, Zaridze DG: Cancer mortality among women in the Russian printing industry. Am J Ind Med 1999, 36:166-71.

110. Lynge E, Rix BA, Villadsen E, Andersen I, Hink M, Olsen E, Møller UL, Silfverberg E: Cancer in printing workers in Denmark. Occup Environ Med 1995, 52(11):738-44.

111. Kvam BM, Romundstad PR, Boffetta $P$, Andersen A: Cancer in the Norwegian printing industry. Scand J Work Environ Health 2005, 31(1):36-43.

112. Boffetta P, Jourenkova N, Gustavsson P: Cancer risk from occupational and environmental exposure to polycyclic aromatic hydrocarbons. Cancer Causes Control 1997, 8(3):444-72.

113. Breslin P: Mortality Among Foundry men in Steel Mills. In Dusts and Disease. Edited by Lemen R, Dement J. Park Forest South: Pathotox Publishers; 1979:439-47.

114. Decoufle $P$, Wood DJ: Mortality patterns among workers in a gray iron foundry. Am J Epidemiol 1979, 109(6):667-75.

115. Andjelkovich DA, Mathew RM, Richardson RB, Levine RJ: Mortality of iron foundry workers: I. Overall findings. J Occup Med 1990, 32(6):529-40.

116. Hansen ES: Cancer mortality among Danish molders. Am J Ind Med 1991, 20(3):401-9

117. Sherson D, Svane O, Lynge E: Cancer incidence among foundry workers in Denmark. Arch Environ Health 1991, 46(2):75-81. 
118. Sorahan T, Faux AM, Cooke MA: Mortality among a cohort of United Kingdom steel foundry workers with special reference to cancers of the stomach and lung, 1946-90. Occup Environ Med 1994, 51(5):316-22.

119. Mallin K: A nested case-control study of bladder cancer incidence in a steel manufacturing plant. Am J Ind Med 1998, 34:393-8.

120. Moulin JJ, Clavel T, Roy D, Dananche B, Marquis N, Fevotte J, Fontana JM: Risk of lung cancer in workers producing stainless steel and metallic alloys. Int Arch Occup Environ Health 2000, 73(3):171-80.

121. Evanoff BA, Gustavsson P, Hogstedt C: Mortality and incidence of cancer in a cohort of Swedish chimney sweeps: an extended follow up study. Br J Ind Med 1993, 50:450-9.

122. Doll R, Vessey MP, Beasley RW, Buckley AR, Fear EC, Fisher RE, Gammon EJ, Gunn W, Hughes GO, Lee K, Norman-Smith B: Mortality of gasworkers final report of a prospective study. Br J Ind Med 1972, 29:394-406.

123. Gustavsson $P$, Reuterwall C: Mortality and incidence of cancer among Swedish gas workers. Br J Ind Med 1990, 47:169-74.

124. Bosetti C, Boffetta P, La Vecchia C: Occupational exposures to polycyclic aromatic hydrocarbons, and respiratory and urinary tract cancers: a quantitative review to 2005. Ann Oncol 2007, 18:431-46.

125. Bender AP, Parker DL, Johnson RA, Scharber WK, Williams AN, Marbury MC, Mandel JS: Minnesota highway maintenance worker study: cancer mortality. Am J Ind Med 1989, 15(5):545-56.

126. Hammond EC, Selikoff IJ, Lawther PL, Seidman H: Inhalation of benzpyrene and cancer in man. Ann N Y Acad Sci 1976, 271:116-24.

127. Partanen T, Boffetta P: Cancer risk in asphalt workers and roofers: review and meta-analysis of epidemiologic studies. Am J Ind Med 1994, 26(6):721-40.

128. Stern FB, Ruder AM, Chen G: Proportionate mortality among unionized roofers and waterproofers. Am J Ind Med 2000, 37:478-92.

129. IARC Working Group on the Evaluation of Carcinogenic Risks to Humans: Diesel and Gasoline Engine Exhausts and Some Nitroarenes, Volume 46. Lyon: IARC; 1989:27.

130. IARC Working Group on the Evaluation of Carcinogenic Risks to Humans: Some Non-heterocyclic Polycyclic Aromatic Hydrocarbons and SomeRelated Exposures. Lyon: IARC; 2010:868.

131. Boffetta P, Silverman DT: A meta-analysis of bladder cancer and diesel exhaust exposure. Epidemiology 2001, 12:125-30.

132. Manju L, George PS, Mathew A: Urinary bladder cancer risk among motor vehicle drivers: a meta-analysis of the evidence, 1977-2008. Asian Pac J Cancer Prev 2009, 10:287-94.

133. Calvert GM, Ward E, Schnorr TM, Fine $L$ : Cancer risks among workers exposed to metalworking fluids: a systematic review. Am J Ind Med 1998, 33:282-92.

134. Howe GR, Burch JD, Miller AB, Cook GM, Esteve J, Morrison B, Gordon P, Chambers LW, Fodor G, Winsor GM: Tobacco use, occupation, coffee, various nutrients, and bladder cancer. J Natl Cancer Inst 1980, 64(4):701-13.

135. Schifflers E, Jamart J, Renard V: Tobacco and occupation as risk factors in bladder cancer: a case-control study in southern Belgium. Int J Cancer 1987, 39(3):287-92.

136. Siemiatycki J, Dewar R, Nadon L, Gerin M, Richardson L, Wacholder S: Associations between several sites of cancer and twelve petroleumderived liquids. Results from a case-referent study in Montreal. Scand J Work Environ Health 1987, 13(6):493-504.

137. Silverman DT, Levin LI, Hoover RN, Hartge P: Occupational risks of bladder cancer in the United States: I. White men. J Natl Cancer Inst 1989, 81(19):1472-80.

138. Gonzalez CA, Lopez-Abente G, Errezola M, Escolar A, Riboli E, Izarzugaza I, Nebot M: Occupation and bladder cancer in Spain: a multi-centre case-control study. Int J Epidemiol 1989, 18(3):569-77.

139. Friesen MC, Costello S, Eisen EA: Quantitative exposure to metalworking fluids and bladder cancer incidence in a cohort of autoworkers. Am J Epidemiol 2009, 169:1471-8

140. Colt JS, Karagas MR, Schwenn M, Baris D, Johnson A, Stewart P, Verrill C, Moore LE, Lubin J, Ward MH, Samanic C, Rothman N, Cantor KP, Beane Freeman LE, Schned A, Cherala S, Silverman DT: Occupation and bladder cancer in a population-based case-control study in Northern New England. Occup Environ Med 2011, 68:239-49.

141. IARC Working Group on the Evaluation of Carcinogenic Risks to Humans: Occupational Exposures in Paint Manufacture and Painting. Lyon: IARC; 1989
142. Yamaguchi N, Watanabe S, Okubo T, Takahashi K: Work-related bladder cancer risks in male Japanese workers: estimation of attributable fraction and geographical correlation analysis. Jpn J Cancer Res 1991, 82(6):624-31.

143. Bosetti C, Pira E, La Vecchia C: Bladder cancer risk in painters: a review of the epidemiological evidence, 1989-2004. Cancer Causes Control 2005, 16(9):997-1008.

144. Gaertner RR, Trpeski L, Johnson KC: A case-control study of occupational risk factors for bladder cancer in Canada. Cancer Causes Control 2004, 15(10):1007-19.

145. Pelucchi C, La Vecchia C, Negri E, Dal Maso L, Franceschi S: Smoking and other risk factors for bladder cancer in women. Prev Med 2002, 35:114-20.

146. Zheng T, Cantor KP, Zhang Y, Lynch CF: Occupation and bladder cancer: a population-based, case-control study in lowa. J Occup Environ Med 2002, 44(7):685-91.

147. Siemiatycki J, Dewar R, Nadon L, Gerin M: Occupational risk factors for bladder cancer: results from a case-control study in Montreal, Quebec, Canada. Am J Epidemiol 1994, 140(12):1061-80.

148. Guha N, Steenland NK, Merletti F, Altieri A, Cogliano V, Straif K: Bladder cancer risk in painters: a meta-analysis. Occup Environ Med 2010, 67(8):568-73.

149. Bachand A, Mundt KA, Mundt DJ, Carlton LE: Meta-analyses of occupational exposure as a painter and lung and bladder cancer morbidity and mortality 1950-2008. Crit Rev Toxicol 2010, 40(2):101-25.

150. Vena JE, Sultz HA, Fiedler RC, Barnes RE: Mortality of workers in an automobile engine and parts manufacturing complex. Br J Ind Med 1985, 42:85-93.

151. Park RM, Mirer FE: A survey of mortality at two automotive engine manufacturing plants. Am J Ind Med 1996, 30:664-73.

152. IARC Working Group on the Evaluation of Carcinogenic Risks to Humans: Dry Cleaning, Some Chlorinated Solvents and Other Industrial Chemicals, Volume 63. Lyon: IARC; 1995:565.

153. Blair A, Stewart PA, Tolbert PE, Grauman D, Moran FX, Vaught J, Rayner J: Cancer and other causes of death among a cohort of dry cleaners. $\mathrm{Br} J$ Ind Med 1990, 47(3):162-8.

154. Ruder AM, Ward EM, Brown DP: Cancer mortality in female and male dry-cleaning workers. J Occup Med 1994, 36(8):867-74.

155. Mundt KA, Birk T, Burch MT: Critical review of the epidemiological literature on occupational exposure to perchloroethylene and cancer. Int Arch Occup Environ Health 2003, 76(7):473-91.

156. Blair A, Petralia SA, Stewart PA: Extended mortality follow-up of a cohort of dry cleaners. Ann Epidemiol 2003, 13:50-6.

157. Swanson GM, Burns PB: Cancer incidence among women in the workplace: a study of the association between occupation and industry and 11 cancer sites. J Occup Environ Med 1995, 37(3):282-7.

158. Lynge $E$, Andersen A, Rylander L, Tinnerberg H, Lindbohm ML, Pukkala E, Romundstad $\mathrm{P}$, Jensen $\mathrm{P}$, Clausen LB, Johansen $\mathrm{K}$ : Cancer in persons working in dry cleaning in the Nordic countries. Environ Health Perspect 2006, 114(2):213-9

159. Selden Al, Ahlborg G Jr: Cancer morbidity in Swedish dry-cleaners and laundry workers: historically prospective cohort study. Int Arch Occup Environ Health 2011, 84(4):435-43.

160. Viel JF, Challier B: Bladder cancer among French farmers: does exposure to pesticides in vineyards play a part? Occup Environ Med 1995, 52:587-92.

161. Michelotti FW: Hazardous chemical safety in the laboratory. Anal Chem 1979, 51(4):441A-56A.

162. Brown TP, Paulson J, Pannett B, Coupland C, Coggon D, Chilvers CE, Sasco AJ: Mortality pattern among biological research laboratory workers. Br J Cancer 1996, 73(9):1152-5.

163. Chiazze L Jr, Walf $P$, Ference LD: An historical cohort study of mortality among salaried research and development workers of the Allied Corporation. J Occup Med 1986, 28(11):1185-8.

164. Dosemeci M, Alavanja M, Vetter R, Eaton B, Blair A: Mortality among laboratory workers employed at the U.S. Department of Agriculture. Epidemiology 1992, 3(3):258-62.

165. Gustavsson P, Reuterwall C, Sadigh J, Soderholm M: Mortality and cancer incidence among laboratory technicians in medical research and routine laboratories (Sweden). Cancer Causes Control 1999, 10(1):59-64.

166. Wennborg H, Yuen J, Axelsson G, Ahlbom A, Gustavsson P, Sasco AJ: Mortality and cancer incidence in biomedical laboratory personnel in Sweden. Am J Ind Med 1999, 35:382-9. 
167. Daly L, Herity B, Bourke GJ: An investigation of brain tumours and other malignancies in an agricultural research institute. Occup Environ Med 1994, 51(5):295-8.

168. Steineck G, Plato N, Alfredsson L, Norell SE: Industry-related urothelial carcinogens: application of a job-exposure matrix to census data. Am J Ind Med 1989, 16(2):209-24.

169. Karlehagen S, Andersen A, Ohlson CG: Cancer incidence among creosote-exposed workers. Scand J Work Environ Health 1992, 18(1):26-9.

170. Wong O, Harris F: Retrospective cohort mortality study and nested casecontrol study of workers exposed to creosote at 11 wood-treating plants in the United States. J Occup Environ Med 2005, 47:683-97.

171. Kjuus $H$, Andersen $A$, Langard S: Incidence of cancer among workers producing calcium carbide. Br J Ind Med 1986, 43:237-42.

172. Miller BG, Cowie HA, Middleton WG, Seaton A: Epidemiologic studies of Scottish oil shale workers: III. Causes of death. Am J Ind Med 1986, 9(5):433-46.

173. Hodgson JT, Jones RD: A mortality study of carbon black workers employed at five United Kingdom factories between 1947 and 1980. Arch Environ Health 1985, 40(5):261-8.

174. Dell LD, Mundt KA, Luippold RS, Nunes AP, Cohen L, Burch MT, Heidenreich MJ, Bachand AM, International Carbon Black Association: A cohort mortality study of employees in the U.S. carbon black industry. J Occup Environ Med 2006, 48:1219-29.

175. Wellmann J, Weiland SK, Neiteler G, Klein G, Straif K: Cancer mortality in German carbon black workers 1976-98. Occup Environ Med 2006, 63:513-21.

176. Puntoni R, Ceppi M, Gennaro V, Ugolini D, Puntoni M, La Manna G, Casella C, Merlo DF: Occupational exposure to carbon black and risk of cancer. Cancer Causes Control 2004, 15:511-6.

177. Moulin JJ, Wild P, Mur JM, Lafontaine M, Lefer M, Mercier-Gallay M, Villemot P, Whebi V, Coulon JP: Risk of lung, larynx, pharynx and buccal cavity cancers among carbon electrode manufacturing workers. Scand J Work Environ Health 1989, 15(1):30-7.

178. Donato F, Monarca S, Marchionna G, Rossi A, Cicioni C, Chiesa R, Colin D, Boffetta P: Mortality from cancer and chronic respiratory diseases among workers who manufacture carbon electrodes. Occup Environ Med 2000, 57(7):484-7.

179. Merlo DF, Garattini S, Gelatti U, Simonati C, Covolo L, Ceppi M, Donato F: A mortality cohort study among workers in a graphite electrode production plant in Italy. Occup Environ Med 2004, 61(2):e9.

180. Lloyd JW, Lundin FE Jr, Redmond CK, Geiser PB: Long-term mortality study of steelworkers. IV. Mortality by work area. J Occup Med 1970, 12(5):151-7.

181. Costantino JP, Redmond CK, Bearden A: Occupationally related cancer risk among coke oven workers: 30 years of follow-up. J Occup Environ Med 1995, 37(5):597-604

182. Franco F, Chellini E, Seniori Costantini A, Gioia A, Carra G, Paolinelli F, Martelli C, Vigotti M: Mortality in the coke oven plant of Carrara, Italy. Med Lav 1993, 84(6):443-7.

183. Chau N, Bertrand JP, Mur JM, Figueredo A, Patris A, Moulin JJ, Pham QT: Mortality in retired coke oven plant workers. Br J Ind Med 1993, 50(2):127-35.

184. Giberti C, Gallo F, Schenone M, Genova A: Early Results of Urothelial Carcinoma Screening in a Risk Population of Coke Workers: Urothelial Carcinoma Among Coke Workers, Biomed Environ Sci. United States: 2010 The Editorial Board of Biomedical and Environmental Sciences. Published by Elsevier B.V; 2010:300-4.

185. Bye T, Romundstad PR, Ronneberg A, Hilt B: Health survey of former workers in a Norwegian coke plant: Part 2. Cancer incidence and cause specific mortality. Occup Environ Med 1998, 55(9):622-6.

186. Swaen GM, Slangen JJ, Volovics A, Hayes RB, Scheffers T, Sturmans F: Mortality of coke plant workers in The Netherlands. Br J Ind Med 1991, 48(2):130-5.

187. Lafontaine M, Payan JP, Delsaut $P$, Morele $Y$ : Polycyclic aromatic hydrocarbon exposure in an artificial shooting target factory: assessment of 1-hydroxypyrene urinary excretion as a biological indicator of exposure. Ann Occup Hyg 2000, 44:89-100.

188. Goutet $P$ : Evolution des expositions industrielles aux cancérogènes vésicaux - approche par secteurs industriels. In Cancers de la vessie et risques professionnels. Edited by Héry M. Les Ulis: EDP Sciences; 2009:89-112.

189. Mian C, Lodde M, Comploj E, Negri G, Egarter-Vigl E, Lusuardi L, Palermo S, Marberger M, Pycha A: Liquid-based cytology as a tool for the performance of uCyt + and Urovysion Multicolour-FISH in the detection of urothelial carcinoma. Cytopathology 2003, 14:338-42.

190. Schroeder GL, Lorenzo-Gomez MF, Hautmann SH, Friedrich MG, Ekici S Huland $\mathrm{H}$, Lokeshwar $\mathrm{V}$ : A side by side comparison of cytology and biomarkers for bladder cancer detection. J Urol 2004, 172:1123-6.

191. May M, Hakenberg OW, Gunia S, Pohling P, Helke C, Lubbe L, Nowack R, Siegsmund $M$, Hoschke $B$ : Comparative diagnostic value of urine cytology, UBC-ELISA, and fluorescence in situ hybridization for detection of transitional cell carcinoma of urinary bladder in routine clinical practice. Urology 2007, 70:449-53.

192. Meiers I, Singh H, Hossain D, Lang K, Liu L, Qian J, Verhest AP, Bostwick DG: Improved filter method for urine sediment detection of urothelial carcinoma by fluorescence in situ hybridization. Arch Pathol Lab Med 2007, 131:1574-7.

193. Messing EM, Teot L, Korman H, Underhill E, Barker E, Stork B, Qian J, Bostwick DG: Performance of urine test in patients monitored for recurrence of bladder cancer: a multicenter study in the United States. J Urol 2005, 174:1238-41

194. Piaton E, Daniel L, Verriele V, Dalifard I, Zimmermann U, Renaudin K, Gobet F, Caratero A, Desvaux D, Pouille Y, Seigneurin D, French Prospective Multicenter Study: Improved detection of urothelial carcinomas with fluorescence immunocytochemistry (uCyt + assay) and urinary cytology: results of a French prospective multicenter study. Lab Invest 2003 83:845-52.

195. Poulakis V, Witzsch U, De Vries R, Altmannsberger HM, Manyak MJ, Becht E A comparison of urinary nuclear matrix protein-22 and bladder tumour antigen tests with voided urinary cytology in detecting and following bladder cancer: the prognostic value of false-positive results. BJU Int 2001, 88:692-701.

196. Takeuchi Y, Sawada Y, Yabuki D, Masuda E, Satou D, Kuroda K, Tajima M, Sawamura Y, Matsushima M: Clinical study of urine NMP 22 (nuclear matrix protein 22) as a tumor marker in urinary epithelial cancer. Aktuelle Urol 2003, 34:265-6.

197. Talwar R, Sinha T, Karan SC, Doddamani D, Sandhu A, Sethi GS, Srivastava A, Narang V, Agarwal A, Adhlakha N: Voided urinary cytology in bladder cancer: is it time to review the indications? Urology 2007, 70:267-71.

198. Bhuiyan J, Akhter J, O'Kane DJ: Performance characteristics of multiple urinary tumor markers and sample collection techniques in the detection of transitional cell carcinoma of the bladder. Clin Chim Acta 2003, 331:69-77.

199. Boman H, Hedelin H, Jacobsson S, Holmang S: Newly diagnosed bladder cancer: the relationship of initial symptoms, degree of microhematuria and tumor marker status. J Urol 2002, 168:1955-9.

200. Halling KC, King W, Sokolova IA, Karnes RJ, Meyer RG, Powell EL, Sebo TJ, Cheville JC, Clayton AC, Krajnik KL, Ebert TA, Nelson RE, Burkhardt HM, Ramakumar S, Stewart CS, Pankratz VS, Lieber MM, Blute ML, Zincke $H_{\text {, }}$ Seelig SA, Jenkins RB, O'Kane DJ: A comparison of BTA stat, hemoglobin dipstick, telomerase and Vysis UroVysion assays for the detection of urothelial carcinoma in urine. J Urol 2002, 167:2001-6.

201. Parekattil SJ, Fisher HA, Kogan BA: Neural network using combined urine nuclear matrix protein-22, monocyte chemoattractant protein-1 and urinary intercellular adhesion molecule-1 to detect bladder cancer. $J$ Urol 2003, 169:917-20.

202. Saad A, Hanbury DC, McNicholas TA, Boustead GB, Morgan S, Woodman AC: A study comparing various noninvasive methods of detecting bladder cancer in urine. BJU Int 2002, 89:369-73.

203. Mowatt G, Zhu S, Kilonzo M, Boachie C, Fraser C, Griffiths TR, N'Dow J, Nabi G, Cook J, Vale L: Systematic review of the clinical effectiveness and cost-effectiveness of photodynamic diagnosis and urine biomarkers (FISH, ImmunoCyt, NMP22) and cytology for the detection and follow-up of bladder cancer. Health Technol Assess 2010, 14:1-331.

204. Tetu B, Tiquert R, Harel F, Fradet Y: ImmunoCyt/uCyt + improves the sensitivity of urine cytology in patients followed for urothelial carcinoma. Mod Pathol 2005, 18:83-9.

205. Tritschler S, Scharf S, Karl A, Tilki D, Knuechel R, Hartmann A, Stief CG, Zaak D: Validation of the diagnostic value of NMP22 BladderChek test as a marker for bladder cancer by photodynamic diagnosis. Eur Urol 2007, 51:403-7. discussion 407-8.

206. Choi HS, Lee SI, Kim DJ, Jeong TY: Usefulness of the NMP22 bladder chek test for screening and follow-up of bladder cancer. Korean J Urol 2010 51:88-93. 
207. Grossman HB, Messing E, Soloway M, Tomera K, Katz G, Berger Y, Shen Y: Detection of bladder cancer using a point-of-care proteomic assay. JAMA 2005, 293:810-6.

208. Hwang EC, Choi HS, Jung SI, Kwon DD, Park K, Ryu SB: Use of the NMP22 bladder chek test in the diagnosis and follow-Up of urothelial cancer: a cross-sectional study. Urology 2011, 77:154-9.

209. Kumar A, Kumar R, Gupta NP: Comparison of NMP22 bladder chek test and urine cytology for the detection of recurrent bladder cancer. Jpn J Clin Oncol 2006, 36:172-5.

210. Lodde M, Mian C, Negri G, Berner L, Maffei N, Lusuardi L, Palermo S, Marberger M, Brssner C, Pycha A: Role of $\mathrm{uCyt}+$ in the detection and surveillance of urothelial carcinoma. Urology 2003, 61:243-7.

211. Messing EM, Young TB, Hunt VB, Gilchrist KW, Newton MA, Bram LL, Hisgen WJ, Greenberg EB, Kuglitsch ME, Wegenke JD: Comparison of bladder cancer outcome in men undergoing hematuria home screening versus those with standard clinical presentations. Urology 1995, 45:387-96.

212. Olsson H, Zackrisson B: ImmunoCyt a useful method in the follow-up protocol for patients with urinary bladder carcinoma. Scand I Urol Nephrol 2001, 35:280-2.

213. Schmitz-Drager BJ, Tirsar LA, Schmitz-Drager C, Dorsam J, Mellan Z, Bismarck E, Ebert T: Immunocytology in the assessment of patients with asymptomatic hematuria. World J Urol 2008, 26:31-7.

214. Junker K, Fritsch T, Hartmann A, Schulze W, Schubert J: Multicolor fluorescence in situ hybridization (M-FISH) on cells from urine for the detection of bladder cancer. Cytogenet Genome Res 2006, 114:279-83.

215. Kipp BR, Halling KC, Campion MB, Wendel AJ, Karnes RJ, Zhang J, Sebo TJ: Assessing the value of reflex fluorescence in situ hybridization testing in the diagnosis of bladder cancer when routine urine cytological examination is equivocal. J Urol 2008, 179:1296-301.

216. Sarosdy MF, Kahn PR, Ziffer MD, Love WR, Barkin J, Abara EO, Jansz K, Bridge $J A$, Johansson SL, Persons DL, Gibson JS: Use of a multitarget fluorescence in situ hybridization assay to diagnose bladder cancer in patients with hematuria. J Urol 2006, 176:44-7.

217. Skacel M, Fahmy M, Brainard JA, Pettay JD, Biscotti CV, Liou LS, Procop GW, Jones JS, Ulchaker J, Zippe CD, Tubbs RR: Multitarget fluorescence in situ hybridization assay detects transitional cell carcinoma in the majority of patients with bladder cancer and atypical or negative urine cytology. J Urol 2003, 169:2101-5.

218. Yoder BJ, Skacel M, Hedgepeth R, Babineau D, Ulchaker JC, Liou LS, Brainard JA, Biscotti CV, Jones JS, Tubbs RR: Reflex UroVysion testing of bladder cancer surveillance patients with equivocal or negative urine cytology: a prospective study with focus on the natural history of anticipatory positive findings. Am J Clin Pathol 2007, 127:295-301.

219. Pesch B, Taeger D, Johnen G, Gawrych K, Bonberg N, Schwentner C, Wellhäusser H, Kluckert M, Leng G, Nasterlack M, Lotan Y, Stenzl A, Brüning T, UroScreen Study Group: The UroScreen study group: screening for bladder cancer with urinary tumor markers in chemical workers with exposure to aromatic amines. Int Arch Occup Environ Health 2013. [Epub ahead of print].

220. Brown T, Slack R, Rushton L, British Occupational Cancer Burden Study Group: Occupational cancer in Britain. Urinary tract cancers: bladder and kidney. Br J Cancer 2012, 107(Suppl 1):S76-84.

221. Golka K, Abreu-Villaca Y, Anbari Attar R, Angeli-Greaves M, Aslam M, Basaran N, Belik R, Butryee C, Dalpiaz O, Dzhusupov K, Ecke TH, Galambos H, Galambos H, Gerilovica H, Gerullis H, Gonzalez PC, Goossens ME, GorgishviliHermes L, Heyns CF, Hodzic J, Ikoma F, Jichlinski P, Kang BH, Kiesswetter E, Krishnamurthi K, Lehmann ML, Martinova I, Mittal RD, Ravichandran B, Romics I, et al: Bladder cancer documentation of causes: multilingual questionnaire, 'bladder cancer doc'. Front Biosci (Elite Ed) 2012, 4:2809-22.

222. Schops W, Jungmann O, Zumbe J, Zellner M, Hengstler JG, Golka K: Assessment criteria for compensation of occupational bladder cancer. Front Biosci (Elite Ed) 2013, 5:653-61.

\section{doi:10.1186/1471-2458-14-1155}

Cite this article as: Clin and Pairon: Medical follow-up for workers exposed to bladder carcinogens: the French evidence-based and pragmatic statement. BMC Public Health 2014 14:1155.

\section{Submit your next manuscript to BioMed Central and take full advantage of:}

- Convenient online submission

- Thorough peer review

- No space constraints or color figure charges

- Immediate publication on acceptance

- Inclusion in PubMed, CAS, Scopus and Google Scholar

- Research which is freely available for redistribution

Submit your manuscript at www.biomedcentral.com/submit
() Biomed Central 